\title{
TAKT PERFORMANCE INDICATORS
}

\author{
Celine G. Haugen ${ }^{1}$, Ola Læadre ${ }^{2}$, and Sigmund Aslesen ${ }^{3}$
}

\begin{abstract}
There is a general perception among researchers that the practice of takt varies within projects. Takt planning relies on collaboration between the production team members, who transform a production strategy into a production schedule. One of the goals of the method is to create flow, and hereby allow construction processes to be efficiently executed.

Workflow within construction has been measured with different methods: observation, self-evaluation and Last Planner ${ }^{\mathrm{TM}}$ System (LPS). To achieve workflow, challenges must be removed. Hence, the novel contribution of this paper is to highlight (1) general challenges expected during the takt plan-execution and (2) takt performance indicators that reveal these challenges. After a longitudinal case study, this paper presents 16 challenges and 7 indicators which together give a foundation for further research of workflow within other Takt Planning and Takt Control-projects.
\end{abstract}

\section{KEYWORDS}

Takt Planning and Takt Control (TPTC), Workflow, Standardization, Lean construction, Performance indicators

\section{INTRODUCTION}

There is a general perception among researchers that the practice of takt varies within each project. Takt planning relies on collaboration between the production team members, who transform a production strategy into a detailed, balanced and feasible production schedule (Frandson et al. 2015).

In the Norwegian construction industry, Veidekke is among the few contractors which is familiar with takt. Veidekke has applied takt since 2010 (Gardarsson et al. 2019), and one recent takt-project is the residential construction project "Ulvenparken" in Oslo. This project includes 342 apartments divided on two buildings, namely "Skrinet" with a total of 318 apartments divided on 3 units and "Prismet" with 24 apartments. The two buildings share a parking lot with 175 spaces. In addition, Skrinet has a commercial space on the ground floor and Prismet includes a large kindergarten. Planning started in summer 2016, foundation work began in January 2019 and handover of the first apartments is expected autumn 2021. The takt planning began in July 2018, and the takt started late December 2019.

1 MSc student, Department of Civil and Environmental Engineering, The Norwegian University of Science and Technology (NTNU), Trondheim, Norway, +47 97043 033, celine.haugen@yahoo.no, orcid.org/0000-0003-2149-9616

2 Professor, dr. ing., Department of Civil and Environmental Engineering, The Norwegian University of Science and Technology (NTNU), ola.ladre@ntnu.no, orcid.org/0000-0003-4604-8299

3 Head of Research and Improvement, Veidekke AS, P.O. Box 506 Skøyen, N-0214 Oslo, Norway; Sigmund.aslesen@veidekke.no, orcid.org/0000-0002-5097-2794 
The takt at Ulvenparken is limited to interior activities, from installation of steel in interior walls to final cleaning. In total, this involved 10 different trades. The takt planning team represented six trades: carpentering, plumbing, ventilation, electricity, kitchen installation and painting. Throughout 4 workshops, this planning team made the takt plan after an introduction to the concept. The planning was structured after the six steps for developing a takt plan and five adjustment mechanisms for making the takt plan more flexible as suggested by Frandson et al. (2013, 2014). All necessary activities were systematized into 16 suitable wagons. Since all trades in the planning team were organized in a joint venture called Team Veidekke DA ${ }^{4}$, specially established for Ulvenparken, they planned with a holistic perspective in consistent with the suggestions of Frandson and Tommelein (2016) and Binninger et al. (2018). In advance of this paper it is carried out a preliminary case study on Ulvenparken. This case study investigated how Team Veidekke DA considered practising takt, mapped possible challenges during the takt planning and the takt plan execution, as well as how to handle these challenges. Throughout the planning of the interior work in takt, Ulvenparken were utilizing the principles of the Last Planner ${ }^{\mathrm{TM}}$ System (LPS), and the members of the takt planning team were members of the Last Planner team.

Challenges during takt plan execution has been documented (Etges et al. 2018; Vatne and Drevland 2016; Frandson and Tommelein 2016; Frandson et al. 2013 etc.), but still a complete set of general challenges concerning the takt is missing. Here, general challenges mean obstacles to achieving the objectives of takt, rather than obstacles linked to a specific type of projects (such as residential construction, hospitals, infrastructure etc.). Therefore, there is a need for more data gathering and analyses to help Takt Planning and Takt Control (TPTC)-projects identify and reduce the number of obstacles (Alhava et al. 2019). To reduce this need, the following research questions will be studied:

- What general challenges are expected during the takt plan execution?

- Which takt performance indicators can identify these challenges?

Veidekke has several ongoing projects that utilizes takt, but this paper analyses the execution of takt at Ulvenparken. To make the research work bearable only the 6 first out of 16 wagons were studied. Limited attention was paid to buffers since they represent waste. However, buffers are important within TPTC-projects because they ensure flexibility.

General challenges relevant for execution were identified in the preliminary case study, carried out during the takt planning.

\section{METHOD}

This paper will report on a longitudinal constructive research within takt. According to March et al. (1995) constructive research involves four activities: (1) building an artefact (the method of TPTC), (2) evaluating an artefact, (3) theorizing why the artefact works or doesn't (challenges), and (4) using evidence (performance indicators) to draw the conclusion. The aim is to solve a practical problem (in this case to maintain workflow throughout execution) and improve existing theory. For these four activities, a general literature review, a case study, a document study, 8 interviews and measurements of seven indicators were used.

A literature review was performed to understand takt and its evolution. The review followed Arksey and O'Malley's (2002) prescriptions for scoping studies. When

4 DA corresponds to general partnership with shared liability. 
identifying relevant studies, papers from IGLC, Oria (online university library) and Google Scholar were used. Additionally, forward and backward snowballing ${ }^{5}$ were applied.

A case study; a detailed investigation of one phenomenon seen as a part of a larger set of parallel instances (Feagin et al. 1991), was suitable for this research. Here, TPTC appeared as the phenomenon, while Ulvenparken was one important instance which could inspire future instances.

A case specific document study was carried out with the purpose of collecting information from Ulvenparken. The documents were of different formats, such as PowerPoint, Excel etc., and contained both qualitative and quantitative information.

The interviews were also case specific, meaning that the 13 interviewees were working at Ulvenparken. The client's, the designers' and the architects' perspectives on takt were excluded since they were neither involved in the takt planning nor the takt control. Within the remaining group, relevant interviewees were naturally limited by the trades that accounted for the first 6 wagons in the analysis period. There have been two rounds of interviews, the first with 5 interviewees in conjunction with the preliminary study and the second with 8 interviewees during the primary research project. In both rounds the interviews were semi-structured and supported by an interview guide.

Finally, measurements were an important data gathering method. The technique was considered as necessary to answer the second research question. To figure out which performance indicators would identify the general challenges expected in the takt plan execution, a list of 5 questions where developed. The questions were:

1. What challenges do we want to measure?

2. Where do we want to measure? (takt area)

3. How are we going to measure? (indicators)

4. When do we want to measure? (point of time)

5. Who shall be measured and who shall measure?

Question 1 was answered within the preliminary study. Out of 32 identified challenges, 16 were considered relevant in the primary research project. They were all connected to the six steps for developing a takt plan and five adjustment mechanisms for making the takt plan more flexible suggested by Frandson et al. (2013, 2014). Since the primary research project was limited to execution, challenges within two of the development steps were omitted, namely 2) Define zones and 3) Understand the trade sequence. The relevant challenges are presented together with the takt performance indicators in table 2 and 3.

Where we wanted to measure (2) was restricted by project progress and similarities in amount of work on each floor. Accordingly, the measurement area was defined to $3^{\text {rd }}$ and $4^{\text {th }}$ floor in unit 1 of Skrinet. These two floors were divided into 3 zones, containing $6\left(1^{\text {st }}\right.$ zone 1$), 5$ ( $2^{\text {nd }}$ zone $)$ and 5 ( $3^{\text {rd }}$ zone $)$ apartments. Figure 1 has a clipart of the takt plan for unit 1. In accordance with Frandson et al. (2013) and Frandson and Tommelein (2016), the measurements were carried out zone by zone.

The answer on how to measure (3) was inspired by literature (Kalsaas et al. 2014; Binninger et al. 2017) accompanied with experiences of the participants in Team Veidekke DA. Techniques for measuring flow in production from the LPS-method appeared as the most favourable for a TPTC-project. A long list of potential performance

\footnotetext{
${ }^{5}$ Forward snowballing means investigating who has cited a source, while backward snowballing means investigating the citations in the source one is looking at (Wohlin 2014).
} 
indicators had to be shortened, and then emphasis was placed on minimising the amount of extra work for all parties involved. The measurements should be functional and contribute positively without seeming burdensome. Seven performance indicators were then selected: (1) percent planned completed (PPC), (2) perfect handovers, (3) overtime, (4) returns, (5) additional choices, (6) man-hours and (7) staffing. These indicators are described further in the results section. To measure them, timesheets collected from the 4 trades constituting the first 6 wagons along with a custom-made protocol inspired by Kalsaas et al. (2014) was used.

Table 1: Handover protocol layout

\begin{tabular}{|c|c|c|c|c|c|c|c|c|c|c|c|c|c|}
\hline \multirow{2}{*}{ Floor } & \multirow{2}{*}{ Unit and zone } & \multicolumn{2}{|c|}{ Zone cleaned? } & \multicolumn{2}{|c|}{ Zone $100 \%$ completed? } & \multicolumn{2}{|c|}{$\begin{array}{l}\text { Any retrogression this } \\
\text { week? }\end{array}$} & \multicolumn{2}{|c|}{$\begin{array}{l}\text { All additional choices } \\
\text { completed? }\end{array}$} & \multicolumn{2}{|c|}{$\begin{array}{l}\text { Executed within normal } \\
\text { work-hours? }\end{array}$} & $\begin{array}{c}\text { From } \\
\text { trade }\end{array}$ & To trade \\
\hline & & Yes & $\begin{array}{c}\text { No } \\
\text { Comments? }\end{array}$ & Yes & $\begin{array}{l}\text { No } \\
\text { What } \\
\text { remains? }\end{array}$ & $\begin{array}{c}\text { Yes } \\
\text { Reason? }\end{array}$ & No & Yes & $\begin{array}{c}\text { No } \\
\text { Comments? }\end{array}$ & Yes & No & Signature & Signn \\
\hline
\end{tabular}

It was decided that it was sufficient to measure (4) the indicators once a week in 12 weeks. The defined 5-day takt time made it natural for measurements to be taken at the end of each takt-week, but what day a takt-week ended was influenced by public holidays.

The fifth question was who should be measured and who should carry out the measurements (5). 6 wagons - explained in figure 2 - moved through 32 apartments. 36 handovers between wagons were done, and each wagon was measured 6 times. In figure 1 the measurement period of 12 weeks is highlighted in blue (to the left), while the black framing shows which wagons that have been measured when.

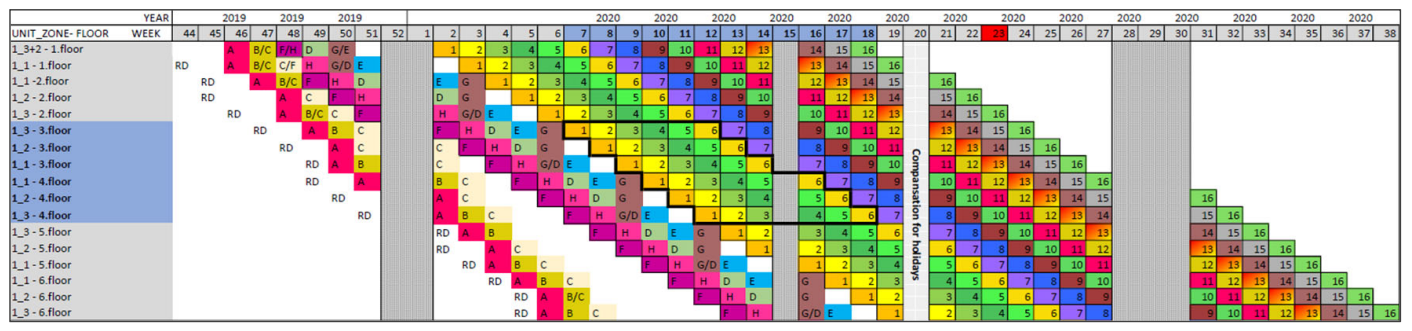

Figure 1: Takt plan for unit 1 in Skrinet - Ulvenparken, with the 12-week measurement period highlighted in blue (Veidekke)

\begin{tabular}{|l|l|l|l|l|l|}
\hline 1. & 2. & 3. & 4. & 5. & 6. \\
$\begin{array}{l}\text { STEEL, } \\
\text { INNER WALLS }\end{array}$ & $\begin{array}{l}\text { PLASTER, } \\
\text { 1.ST LAYER }\end{array}$ & $\begin{array}{l}\text { VENTILATION } \\
\text { DUCTS }\end{array}$ & $\begin{array}{l}\text { ELECTRICAL } \\
\text { PLUMBING }\end{array}$ & $\begin{array}{l}\text { FIRE SPRINKLER } \\
\text { + PRESSURE TEST }\end{array}$ & $\begin{array}{l}\text { PLASTER, } \\
\text { CLOSE WALLS } \\
+ \text { CEILING }\end{array}$ \\
\hline
\end{tabular}

Figure 2: First 6 wagons in the 16-activity sequence

When considering who should perform the measurements, it was important prevent subjective measurements. Therefore, a collaborative system where both the trade that left and trade that received the zone signed a handover protocol. Timesheets were filled out by the crew leaders. To avoid fabrication of "perfect" measurements, regular follow-ups were conducted. Hereby, all timesheets were given to the authors every week, who were allowed to question crew leaders about ambiguous results. 


\section{THEORETICAL FRAMEWORK}

\section{TAKT PLANNING}

The term Takt comes from German and means rhythm. In production, takt appears as the required rate of production to meet the supply demand for that product (Frandson et al. 2013). With this definition, Frandson et al. (2014) - leaning on Ballard (1999) and Tsao et al. (2004) - looks at Takt Planning (TP) as a method for work structuring. The method has a rigid and predetermined structure, with the intention of creating a stable environment for the Last Planner ${ }^{\mathrm{TM}}$ System (LPS). Out of LPS two initial purposes, takt planning is supposed to "improve workflow in production" (Ballard, 2000).

According to Tsao et al. (2000), with inspiration from Ballard (1999), work structuring involves determining:

1. In what chunks ${ }^{6}$ will work be assigned to specialists?

2. How will work chunks be sequenced?

3. How will work be released from one production unit $^{7}$ to the next?

4. Will consecutive production units execute work in a continuous flow process, or will their work be de-coupled?

5. Where will de-coupling buffers be needed and how should they be sized?

6. When will different chunks of work be done?

As stated by Frandson et al. (2013 and 2014), takt planning answers these questions through a process of 6 iterative steps. Figure 3 elaborates on Veidekke's representation of the 6 steps and illustrates the iterative process. The result is called a Takt Plan. As mentioned, only 4 of these steps are relevant when considering expected challenges in the execution phase: 1) Gather information, 4) Balance the workflow, 5) Understand the trade durations, 6) Establish the production plan.

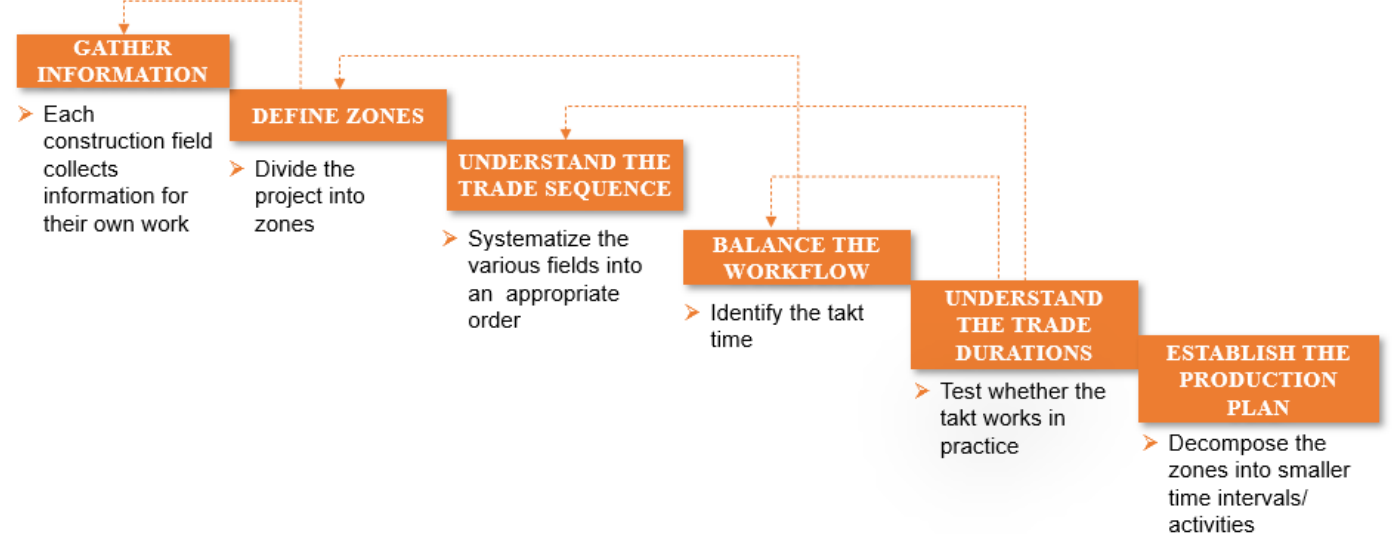

Figure 3: Veidekke's representation of the 6 iterative steps to develop a takt plan

The work structure in takt can be visualised as a train with wagons. Each trade can have more than one wagon in the train. The designated takt-area is divided into suitable zones. The entire train passes through each zone with a speed corresponding to the Takt time.

6 A work "chunk" is a unit of work that can be handed off from one production unit to the next. (Tsao et al. 2000)

7 A "production unit" is an individual or group performing production tasks. Production units are recipients of work assignments. (Tsao et al. 2000) 
Takt time is the available time a trade has per zone. When the last wagon leaves a zone, the allocated work is finished.

The structure of takt can be perceived as too rigid to be adapted to the entire production. Therefore, takt is often applied to certain areas, such as for example interior work. In addition, a takt plan depends on flexibility to be feasible (Binninger et al. 2017). This can be obtained by introducing adjustment mechanisms, such as: 1) hybrid wagons, 2) directional construction process, 3) buffers, 4) standardization and 5) quality assurance.

A wagon may end up having very few tasks within the takt time. Then, so-called hybrid wagons can be used to shorten the total schedule. These wagons consist of several trades that can work simultaneously in a zone.

In Ulvenparken, the zones include several apartments. All wagons should move through the apartments in the same direction, and the directional construction process will contribute to workflow. A directional construction process is beneficial in case of hybrid wagons, as two trades in the same hybrid wagon can avoid working in the same area by starting in different apartments. It is also beneficial in terms of buffers, since wagons that did not complete work within the takt time in their previous zone can continue in the last apartments in the zone without disturbing the new wagon (too) much.

In construction projects, a buffer can handle unforeseen events without significantly affecting the planned production. The number of required buffers depends on the project's variability - the more variety, the more buffers are required (Bølviken et al. 2015). A buffer can be found within the aspects 1) time, 2) capacity, 3) space and 4) plan (Frandson et al. 2015). Time buffer is designed to adjust the available construction time and is rarely used in TPTC-projects. The capacity buffer refers, according to Frandson et al. (2015), to that a wagon normally should need 70-80 \% of maximum crew capacity. A space buffer offers empty spaces, where work can be performed when wagons have unutilised capacity, either because they are ahead of the takt or the wagon up front is lagging behind the takt (Kenley and Seppänen 2010). Plan buffer refers to tasks outside the takt independent of the workflow. These tasks can therefore be performed as a backlog to other tasks. Capacity, space and plan buffers are more common than time buffers in TPTC-projects (Frandson et al. 2015).

Standardisation means creating and implementing standards to ensure a consistent quality. Standards removes variation and guides the creation of a good or service based on the consensus of the relevant parties in the industry (CFI, n.d.). The construction industry has numerous standards. In 2013, Linnik et. al presented an analysis of a project that attempted to apply takt planning on non-repetitive work. The result was patronizing, as the workflow was absent and the project experienced apostasy in the staffing. Considering this research, along with Vatne and Drevland's research (2013), takt is vulnerable for variations.

Quality assurance are planned and systematic activities undertaken to ensure that a good or service meets the quality requirements. Here, the construction industry operates with many different techniques, which together controls the production. According to Kalsaas et al. (2014), handovers in the execution phase is an ideal opportunity where quality is regularly controlled.

\section{TAKT CONTROL}

For a project to succeed with a takt plan, follow-ups and adjustments of the plan are required during the project's development (Haghsheno et al. 2016). The method used to record the necessary changes is called Takt Control (TC). Regular Takt controls maintain 
the stability necessary for takt production (Dlouhy et al. 2018). To achieve proper takt control, two questions need to be answered:

1. How can necessary changes in the takt be identified?

2. How often should the takt be controlled?

According to Kalsaas et al. (2014), workflow within construction has been measured with the help of observations, self-evaluation and LPS. The main difference between these three methods is that LPS addresses workflow between the trades, while observations and self-evaluation also addresses flow within the trades. All the methods intend to identify necessary changes. Since LPS involves measuring workflow - for example measuring if the weekly plan is achieved - this method suits TPTC-projects (Kalsaas et al. 2014).

It is difficult to give a general recommendation on how often a takt control should be performed. Peters et al. (2009) recommended daily takt meetings with all trades and the project management present. This frequent controls can adversely affect the production flow. Following the weekly plans of LPS - with sporadic daily follow-ups - requires less control.

By introducing takt planning and the takt control to some parts of a production, typically the interior work, LPS's aim of creating flow in production can be achieved. The production flow is achieved during the planning phase by creating a rigid plan with flexible mechanisms, while it is maintained during the execution phase through frequent system controls.

Looking at the principles of LPS, the purpose of applying takt can be elaborated in the following 5 points, which later will be used to explain the choice of performance indicators at Ulvenparken:

- The craftsmen should be allowed to work independently

- Achieve a stable staffing and steady on-site workflow

- Avoid several trades working in the same area at the same time

- Punctual deliveries between trades

- Balance it all, while striving for high production rate

\section{RESULTS AND DISCUSSION}

The preliminary study identified 16 challenges with respective indicators connected to the 4 relevant takt plan components and the 5 adjustment mechanisms. The explanations in table 2 and 3 describe how the indicators confirm or reject the challenges. Illness is mentioned twice, since it can cause problems for both takt plan component 4 and 5 . Protocol refers to the handover protocol signed when one wagon leaves and the new wagon enters a zone. Timesheet refers to the number of manhours spent by the trade teams in the wagons. 
Table 2: Challenges and indicators for the 4 relevant takt plan components

\begin{tabular}{|c|c|c|c|}
\hline $\begin{array}{l}\text { TAKT PLAN } \\
\text { COMPONENTS }\end{array}$ & CHALLENGES & $\begin{array}{l}\text { MEASURE TECHNIQUE: } \\
\text { INDICATORS }\end{array}$ & EXPLANATION \\
\hline \multirow{4}{*}{$\begin{array}{l}\text { 1) GATHER } \\
\text { INFORMATION }\end{array}$} & $\begin{array}{c}\text { Inadequate and insufficiently detailed } \\
\text { information }\end{array}$ & Protocol: Returns (4) & $\begin{array}{l}\text { If a great amount of returns was registered, trades may } \\
\text { have given inadequate and insufficiently detailed information } \\
\text { during the takt planning }\end{array}$ \\
\hline & $\begin{array}{l}\text { Honesty within the man-hours } \\
\text { estimate }\end{array}$ & Timesheets: Man-hours (6) & $\begin{array}{l}\text { Low correlation between actual and estimated man-hours } \\
\text { could indicate little honesty in the estimates. }\end{array}$ \\
\hline & Lack of manpower & Protocol/Timesheets: Overtime (3) & Any use of overtime can indicate a lack of manpower. \\
\hline & Achieve steady staffing & Timesheets: Staffing ( 7 ) & $\begin{array}{l}\text { If the staffing is equal throughout the project, the situation is } \\
\text { stable. By registering a controlled reduction in the staffing, } \\
\text { step by step, the situation is also under control. }\end{array}$ \\
\hline $\begin{array}{l}\text { 4) BALANCE THE } \\
\text { WORKFLOW }\end{array}$ & Illness & Timesheets: Staffing (7) & $\begin{array}{l}\text { Large difference between estimated and actual staffing may } \\
\text { indicate illness. In addition, we can look at who is working in } \\
\text { the takt from time to time, where frequent replacements can } \\
\text { confirm the suspicion of sick leave. }\end{array}$ \\
\hline \multirow{2}{*}{$\begin{array}{l}\text { 5) UNDERSTAND THE } \\
\text { TRADE DURATIONS }\end{array}$} & Delays & $\begin{array}{l}\text { Protocol: PPC (1)+ perfect } \\
\text { handovers (2)+ overtime }(3)+ \\
\text { returns }(4)\end{array}$ & $\begin{array}{l}\text { PPU below } 100 \% \text { means that the takt time is not being } \\
\text { followed. If the wagon is not delivered at the agreed time, } \\
\text { overtime is used or there is registered returns, there is a } \\
\text { potential for delays. }\end{array}$ \\
\hline & Illness & Timesheets: Staffing ( 7 ) & $\begin{array}{l}\text { Large difference between estimated and actual staffing may } \\
\text { indicate illness. In addition, If you look at who is working in } \\
\text { the takt at all times, frequent replacements can confirm the } \\
\text { suspicion of sick leave. }\end{array}$ \\
\hline \multirow{2}{*}{$\begin{array}{l}\text { 6) ESTABLISH THE } \\
\text { PRODUCTION PLAN }\end{array}$} & Trades: Obtain control over the takt & Protocol: Perfect handovers (2) & $\begin{array}{l}\text { During the procedure of the protocols, the workers are } \\
\text { reminded of the job they should have completed. } \\
\text { Furthermore, if a perfect handover is registered, they will } \\
\text { feel control over the situation. }\end{array}$ \\
\hline & $\begin{array}{c}\text { Project management: Obtain control } \\
\text { over the takt }\end{array}$ & Protocol: Are the protocols filled out? & $\begin{array}{l}\text { The protocol makes it easy for project management to get a } \\
\text { quick overview of production and detect any problems. } \\
\text { However, to achieve this control the protocols must be filled } \\
\text { out. Construction site visit and meetings will also help to } \\
\text { achieve control. }\end{array}$ \\
\hline
\end{tabular}

Table 3: Challenges and indicators for the 5 adjustment mechanisms

\begin{tabular}{|c|c|c|c|}
\hline $\begin{array}{l}\text { ADJUSTMENT } \\
\text { MECHANISMS }\end{array}$ & CHALLENGES & $\begin{array}{l}\text { MEASURE TECHNIQUE: } \\
\text { INDICATORS }\end{array}$ & EXPLANATION \\
\hline 1) HYBRID WAGONS & $\begin{array}{l}\text { Avoid different trades working in the } \\
\text { same areas at the same time }\end{array}$ & Protocol: Returns (4) & $\begin{array}{l}\text { If a return is recorded, this may indicate that several trades } \\
\text { have shared one zone for a short period. }\end{array}$ \\
\hline $\begin{array}{l}\text { 2) DIRECTIONAL } \\
\text { CONSTRUCTIVE } \\
\text { PROCESS }\end{array}$ & $\begin{array}{l}\text { A directional construction process } \\
\text { should not provide buffer zones }\end{array}$ & Protocol: Returns (4) & $\begin{array}{l}\text { If frequent returns are recorded for one or more trades, this } \\
\text { may indicate that the building direction is used as a buffer } \\
\text { zone. }\end{array}$ \\
\hline \multirow[b]{2}{*}{ 3) BUFFER } & The right number of buffers & No exsisting indicator & - \\
\hline & Low priority on buffer-work & Timesheets: Staffing (7) & $\begin{array}{l}\text { The relationship between the number of workers working } \\
\text { inside and outside the takt, within each trade, may provide } \\
\text { some information about their capacity to perform work in the } \\
\text { buffer zones. }\end{array}$ \\
\hline 4) STANDARDIZATION & Less variation in the work tasks & Timesheets: Staffing (7) & $\begin{array}{l}\text { If the same worker performs the same task over a longer } \\
\text { period, the working day can be defined as less variated. }\end{array}$ \\
\hline \multirow[t]{2}{*}{ 5) QUALITY ASSURANCE } & $\begin{array}{l}\text { Good communication within the } \\
\text { project }\end{array}$ & Protocols: Do every trade sign? & $\begin{array}{l}\text { The protocol is not completed if only one trade signs. The } \\
\text { reason why only one trade has signed can e.g. be poor } \\
\text { communication or little cooperation between the trades. }\end{array}$ \\
\hline & Forget an additional choice & Protocol: Additional choices (5) & $\begin{array}{l}\text { If no additional choices are marked as completed, they may } \\
\text { have been forgotten. }\end{array}$ \\
\hline
\end{tabular}

(1) $P P C$ identifies how much of the planned work that has been performed. At Ulvenparken it was desirable to identify this through the entire protocol. The measuring was in accordance with the technique presented by Kalsaas et al. (2014), where results were recorded by the ratio executed above number of planned wagons for each week. The contribution of this indicator was to achieve a steady workflow. 
A (2) perfect handover was registered in the protocol if two requirements were fulfilled, namely 1) The zone was cleaned and 2) Tasks in the zone were $100 \%$ completed. With a perfect handover, the craftsmen in the new wagon could work independently.

(3) Overtime meant registering hours beyond the normal weekly working hours, like for example hours worked during weekends. The indicator was part of the handover protocol and was used to adjust the staffing.

The returns (4) indicated whether a trade had to return to a previous zone to complete missing work. When registered in the protocol, it could explain why different trades worked in the same area at the same time.

(5) Additional choices were apartment buyers' supplemental choices to the standard apartments. The choices were registered in the protocol, and the indicator compared number of performed additional choices in a zone against the planned number. If the numbers did not correlate, a corrected registration or return was required.

(6) Man-hour refers to the work that one person does in one hour. At Ulvenparken, this indicator was measured through a comparison of estimated work hours and actual work hours taken from the timesheets for each wagon. The estimated work hours were per square meter and indicated if a steady on-site workflow was achieved.

(7) Staffing was compared in the same way as man-hours, with an estimate calculated by dividing the estimated man-hours on a defined working day of 7.5 hours. If the estimated staffing correlated with the actual staffing, the craftsmen could independently and regularly.

At the beginning of the measurement period the project management taught all the trades how the handover protocol worked. On the handover day at the end of the week, follow-ups where conducted on-site to support the crew leaders. Eventually, when the crew leaders were left to themselves, the number of handover protocols was reduced. The black framing in table 4 shows which handover protocols that were supposed to be filled out during the 12 weeks measurement period.

Table 4: Logging of handover protocols

\begin{tabular}{|c|c|c|c|c|c|c|c|}
\hline & \begin{tabular}{c|} 
1) Steel, \\
Inner walls
\end{tabular} & $\begin{array}{l}\text { 2) Plaster, } \\
\text { l.st layer }\end{array}$ & 3) Electrical plumbing & 4) Ventilation ducts & $\begin{array}{c}\text { 5) Fire sprinkler + } \\
\text { Pressure test }\end{array}$ & & $\begin{array}{l}\text { 6) Plaster, Close walls + } \\
\text { Ceiling }\end{array}$ \\
\hline Week 4 & 1_2 & $2 \_3$ & $3 \_4$ & 4_5 & & & \\
\hline Week 5 & $1 \_2$ & $2 \_3$ & $3 \_4$ & 4_5 & & $5 \_6$ & \\
\hline \begin{tabular}{|l|} 
Week 6 \\
\end{tabular} & $1 \_2$ & $2 \_3$ & 344 & 4_5 & & $5 \_6$ & \\
\hline Week 7 & $1 \_2$ & 2_3 & 3_4 & 4_5 & & 5_6 & $6 \_7$ \\
\hline Week 8 & $1 \_2$ & 23 & $3 \_4$ & $4 \_5$ & & $5 \_6$ & $6 \_7$ \\
\hline Week 9 & $1 \_2$ & $2 \_3$ & 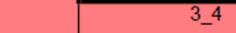 & 4_5 & & $5 \_6$ & $6 \_7$ \\
\hline Week 10 & $1 \_2$ & $2 \_3$ & $3 \_4$ & 4 45 & & $5 \_6$ & $6 \_7$ \\
\hline Week 11 & $1 \_2$ & $2 \_3$ & 3_4 & 4_5 & & $5 \_6$ & $6 \_7$ \\
\hline Week 12 & $1 \_2$ & $2 \_3$ & $3 \_4$ & 4_5 & & $5 \_6$ & 6 \\
\hline Week 13 & $1 \_2$ & $2 \_3$ & $3 \_4$ & 4_5 & & 5_6 & 6_7 \\
\hline Week 14 & $1 \_2$ & $2 \_3$ & $3 \_4$ & 4_5 & & $5 \_6$ & $6 \_7$ \\
\hline \multicolumn{8}{|l|}{ Week 15} \\
\hline Week 16 & $1 \_2$ & $2 \_3$ & 3 -4 & $4 \_5$ & & $5 \_6$ & $6 \_7$ \\
\hline Week 17 & 1_2 & $2 \_3$ & 3_4 & \multicolumn{3}{|c|}{ 4_6 } & $6 \_7$ \\
\hline Week 18 & $1 \_2$ & $2 \_3$ & $3 \_4$ & \multicolumn{3}{|c|}{$4 \_6$} & $6 \_7$ \\
\hline
\end{tabular}

The trend presented above confirms one of the lessons learned by Frandson et al. (2013). Follow-ups and personal support is crucial to achieve a successful production control. According to the lesson learned by Vatne and Drevland (2016) - takt must be introduced at an early stage and involve the craftsmen - the takt plan at Ulvenparken could still be achieved since takt was introduced at an early stage in the planning process along with 
LPS, where the craftsmen were involved through the Last Planners. It should be noted that the follow-up was resumed from week 16 with a considerable positive effect.

Since both wagon 1 and 2 belonged to the carpenters, and their work went fluent, it was decided that handover protocols were not necessary here. Handovers that included wagon 5 were also disregarded, as their work was carried out vertically rather than horisontally, c.f Frandson and Tommelein (2016). Handovers between carriages 4 and 6 were therefore established from week 17. As the handover protocols were not filled out, no results were recorded for indicator 1) PPC, 2) perfect handover, 4) returns nor 5) additional choices during the measurement period. On the other hand, all timesheets were delivered after each takt-week. This has consequently produced some results for indicator 3) overtime, 6) man-hour and 7) staffing.

Indicator 2, 3, 4 and 5 can be registered in a handover protocol. This was confirmed by the interviewees. On the other hand, indicator 1 is a far more comprehensive indicator that should have been measured differently at Ulvenparken. Measuring PPC through the handover protocols was not sufficient, and for the future it may be more efficient to measure PPC as a stand-alone indicator in a more targeted manner. Concerning indicator 6 and 7, the interviewees admitted that the submission of timesheets for the takt control required less work than the protocols. The reason may be that each trade crew was paid a fixed rate for each unit they produced. In turn this required the crew leader to register man-hours for each trade-member every week. Therefore, there has been no issue for the crew leaders to filter out the hours within the takt. The timesheets represented a time efficient way of measuring man-hours and staffing.

\section{CONCLUSION AND FURTHER RESEARCH}

The novel contribution of this paper is to highlight 1) expected challenges that can occur during the takt plan execution and 2) takt performance indicators that can identify these challenges. Based on the results from a preliminary study, totally 16 general challenges for the execution phase (e.g. lack of manpower, illness, delays) were linked to 4 takt plan components and 5 adjustments mechanisms, respectively. To measure these challenges, 7 performance indicators was selected, namely; PPC, perfect handovers, overtime, returns, additional choices, man-hours and staffing. The measurement of the indicators was collected through timesheets and protocols from handover of the takt zones.

Lessons learned from this study is that follow-ups and personal support is crucial to achieve a successful production control in a TPTC- project. Furthermore, indicator 2) perfect handover, 3) overtime, 4) returns and 5) additional choices can be registered in a handover protocol. On the other hand, timesheets are a time efficient way of measuring indicator 6) man-hour and 7) staffing. The indicator 1) PPC could be measure alone, due to its complexity.

According to the limitations of this paper, further research concerning performance indicators in TPTC-projects is needed. First, investigating the 7 indicators within other TPTC-projects is needed. At the same time, it can be useful to study how the measurements progress at Ulvenparken. Another positive contribution to the research would be to analyse a larger number of wagons over a longer time perspective. Second, it would be interesting to take a closer look at the countermeasures for the expected challenges. Other perspectives on takt execution, especially form the clients, would also be of interest. However, this paper contributes in the right direction of developing takt as an even more functional work structuring method. 


\section{REFRENCES}

Alhava, O., Rinne, V., Laine, E. and Koskela, L. 2019, "Can a Takt Plan Ever Survive Beyond the First Contact with the Trades On-Site?" In Proc., 26th Ann. Conf. of the Int'l. Group for Lean Construction, Dublin, Ireland. 453-464 .

Arksey, H., and O'Malley, L. 2005. "Scoping studies: towards a methodological framework." International journal of social research methodology, 8(1), 19-32. https://doi.org/10.1080/1364557032000119616

Ballard, G., 1999. "Work structuring”. Lean Construction Institute, White paper 5. Accessed: 1 February 2020. https://www.leanconstruction.org/media/library/id48/Work_Structuring.pdf.

Ballard, H.G., 2000. The last planner system of production control. $\mathrm{PhD}$ thesis, University of Birmingham, Birmingham UK.

Binninger, M., Dlouhy, J., Müller, M., Schattmann, M., and Haghsheno, S. 2018. "Short Takt Time in Construction - a Practical Study". In Proc., 26th Ann. Conf. of the Int'l. Group for Lean Construction, 1133-1143. Chennai, India.

Binninger, M., Dlouhy, J., Steuer, D. and Haghsheno, S. 2017. “Adjustment Mechanisms for Demandoriented Optimisation in Takt Planning and Takt Control". In Proc., $25^{\text {th }}$ Ann. Conf. of the Int'l. Group for Lean Construction, 613-620. Heraklion, Greece.

Bølviken, T., Aslesen, S. and Koskela, L., 2015. "What is a good plan?". In Proc., 23rd Ann. Conf. of the Int'l. Group for Lean Construction, 93-102. Perth, Australia

CFI n.d. "Standardization". Accessed: 4. February 2020. https://corporatefinanceinstitute.com/resources/knowledge/economics/standardizatio $\mathrm{n} /$.

Dlouhy, J., Binninger, M., Oprach, S. and Haghsheno, S. 2018. "Mastering Complexity in Takt Planning and Takt Control - Using the Three Level Model to Increase Efficiency and Performance in Construction Projects". In Proc., 26th Ann. Conf. of the Int'l. Group for Lean Construction, Chennai, India. 1365-1374.

Etges, B. M. B. da S., Pereira, B. B., and Silveira, T. J. S. da. 2018. "A Lean Approach to Improve Productivity in a Coke Oven Refurbishment Project: A Case Study." In Proc., $26^{\text {th }}$ Ann. Conf. of the Int'l. Group for Lean Construction, 1112-1121. Chennai, India.

Feagin, J. R., Orum, A. M., Sjoberg, G. 1991. "A case for the case study”. Social Force. 71(1). https://doi.org/10.2307/2579984.

Frandson, A., Berghede, K., and Tommelein, I. D. 2013. "Takt time planning for construction of exterior cladding". In Proc., 21st Ann. Conf. of the Int'l. Group for Lean Construction, 527-536, Fortaleza, Brazil.

Frandson, A., Berghede, K., and Tommelein, I. D. 2014. "Takt-time planning and the last planner". In Proc., 22nd Ann. Conf. of the Int'l. Group for Lean Construction, 571580. Oslo, Norway.

Frandson, A.G., Seppänen, O., and Tommelein, I.D. 2015. "Comparison between location based management and Takt Time Planning." In Proc., 23rd Ann. Conf. of the Int'l. Group for Lean Construction, 3-12. Perth, Australia.

Frandson, A., Tommelein, I.D. 2016. "Takt Time Planning of Interiors on a Pre-cast Hospital Project." In Proc., 24th Ann. Conf. of the Int'l. Group for Lean Construction, 143-152. Boston, MA, USA.

Gardarsson, M.H., Lædre, O. and Svalestuen, F. 2019. "Takt time planning in Porsche Consulting, the Boldt Company and Veidekke." In Proc., 27th Ann. Conf. of the Int'l. Group for Lean Construction, 551-562. Dublin, Ireland. 
Haghsheno, S., Binninger, M., Dlouhy, J. and Sterlike, S. 2016. "History and Theoretical Foundations of Takt Planning and Takt Control". In Proc., 23rd Ann. Conf. of the Int'l. Group for Lean Construction, 53-62. Boston, USA.

Kalsaas, B. T., Gundersen, M. and Berge, T. O. 2014. "To Measure Workflow and Waste. A Concept for Continuous Improvement" In Proc., 22nd Ann. Conf. of the Int'l. Group for Lean Construction, 835-846. Oslo, Norway.

Kenley, R. and Seppänen, O. 2010. "Location-Based Management for Construction: Planning, scheduling and control”, pp 237. New York: Spon Press.

Linnik, M. and Berghede, K. 2013. "An Experiment in Takt Time Planning Applied to Non-Repetitive Work” In Proc., 21st Ann. Conf. of the Int'l. Group for Lean Construction, 609-618. Fortaleza, Brazil.

March, S.T. and Smith, G.F. 1995. "Design and natural science research on information technology." Dec. Support Syst., 15 (4) 251-266. https://doi.org/10.1016/01679236(94)00041-2.

Peters, R. 2009. "Shopfloor-Management: Führen am Ort der Wertschöpfung”. Ludwigsburg, Germany: LOG_X.

Tsao, C.Y., Tommelein, I.D., Swanlund, E., and Howell, G.A. 2000. "Case study for work structuring: installation of metal door frames". In Proc., 8th Ann. Conf. of the Int'l. Group for Lean Construction. Brighton, U.K.

Tsao, C.C.Y., Tommelein, I.D., Swanlund, E. and Howell, G.A. 2004. "Work Structuring to Achieve Integrated Product-Process Design". J. Constr. Eng. Management. 130 (6), https://doi.org/10.1061/(ASCE)0733-9364(2004)130:6(780).

Vatne, M. E. and Drevland, F. 2016. "Practical Benefits of Using Takt Time Planning: A Case Study". In Proc., 24th Ann. Conf. of the Int'l. Group for Lean Construction, 173182. Boston, USA.

Wohlin, C. 2014. "Guidelines for Snowballing in Systematic Literature Studies and a Replication in Software Engineering". In EASE '14: 18th International Conference on Evaluation and Assessment in Software Engineering, 1-10. London, England. 